\title{
Preliminary Screening of Corn Silk (Zea mays L.) for Antioxidant Properties and Cytotoxicity Activity on Human Myelogenous Leukemia Cell Line (K562) ${ }^{\dagger}$
}

\author{
Pavatharany Gunasegaran ${ }^{1, *}$, Choo Hui Jing ${ }^{1}$, Norliza Shah Jehan Muttiah ${ }^{1}$, Kokila Thiagarajah ${ }^{1}$ \\ 1 Department of Biological Science, Faculty of Science, Tunku Abdul Rahman University, Jalan Universiti Bandar Barat, \\ 31900, Kampar, Perak \\ * Correspondence: norliza@utar.edu.my; \\ $\dagger$ Presented at International e-Conference on Bioengineering for Health and Environment (ICBHE 2020)
}

Received: 5.07.2020; Revised: 10.07.2020; Accepted: 12.07.2020; Published: 15.07.2020

\begin{abstract}
One of the traditionally used herbs is the byproduct of the maize plant, the 10-20 cm long corn silk which from the female maize flowers. The aim of this study is to evaluate the total phenolic content, antioxidant activity, and cytotoxicity activity of corn silk. The corn silk was minced and was extracted with methanol-water ( $80 \% \mathrm{v} / \mathrm{v})$, methanol, ethanol, ethyl acetate, and hexane by using the maceration method. The total phenolic content (TPC) of corn silk was determined to assess the presence and level of phenolic compounds in each sample. The antioxidant activities of all corn silk extracts were determined via DPPH method, and MTT assay was used to study the viability of the cells after the cells were treated with corn silk extracts at different time intervals. The highest phenolic content was exhibited by the methanol extract. The $\mathrm{EC}_{50}$ value for methanol-water $(80 \% \mathrm{v} / \mathrm{v})$, methanol, ethanol, ethyl acetate and hexane extracts were $251 \mu \mathrm{g} / \mathrm{ml}, 300 \mu \mathrm{g} / \mathrm{ml}, 330 \mu \mathrm{g} / \mathrm{ml}, 550 \mu \mathrm{g} / \mathrm{ml}$ and $1736 \mu \mathrm{g} / \mathrm{ml}$ respectively. The MTT assay, the lowest $\mathrm{IC}_{50}$ values at 24 and 48 hours intervals, was exhibited by methanol-water extract $(104 \mu \mathrm{g} / \mathrm{ml})$. In contrast, methanol $(308 \mu \mathrm{g} / \mathrm{ml})$ was found with the highest $\mathrm{IC}_{50}$ value for all 24,48 , and 72 hours intervals. At 72 hours interval, ethyl acetate $(88 \mu \mathrm{g} / \mathrm{ml})$ shown the lowest $\mathrm{IC}_{50}$ value. This study suggested that corn silk could be potentially used as a source of antioxidant and can further evaluate for cancer studies.
\end{abstract}

Keywords: maize; antioxidant activity; phenolic compounds; $\mathrm{MTT}$ assay; $\mathrm{IC}_{50}$ values.

(c) 2020 by the authors. This article is an open-access article distributed under the terms and conditions of the Creative Commons Attribution (CC BY) license (https://creativecommons.org/licenses/by/4.0/).

\section{Funding}

This research received no external funding.

\section{Acknowledgments}

This study was supported by UTAR.

\section{Conflicts of Interest}

The authors declare no conflict of interest. 